\title{
CHOVÁNÍ ZAMĚSTNANCŮ VE FIRMÁCH JAKO SPOJITOST NA NEZAMĚSTNANOST
}

\author{
Petra Koudelková
}

\section{Klíčová slova:}

Nezaměstnanost, finanční krize, uchazeč o práci, pracovní smlouvy, loajálnost zaměstnanců, vzdělávání

\section{Key words:}

unemployment, financial crisis, applicant for a job, contract of employment, loyalty of employees, education

\begin{abstract}
Abstrakt
Článek se zabývá otázkou nezaměstnanosti v období finanční krize. Kromě srovnání počtu nezaměstnaných lidí před vypuknutím finanční krize a v jejím průběhu, jsem se zabývala $i$ otázkou nedostatku pracovních míst a morálkou zaměstnanců. Právě morálka, loajálnost a hlavně chut' nebo také ochota pracovat jsou velmi důležitými rysy člověka, které se podílí na celkové míře nezaměstnanosti. Také se od ní mnohdy odvíjí životaschopnost podniků a jejich rozvoj. Výzkum byl zpracován v personální agentuře.
\end{abstract}

\begin{abstract}
The paper deals with the issue of unemployment during the financial crisis. In addition to compare the number of unemployed people from the financial meltdown and its course, I also discussed the lack of jobs and employee morale. Important characteristic of human morality is willingness to work and loyalty. This is an important role in unemployment. Also the viability of enterprises depends on willingness to work and loyalty.
\end{abstract}

\section{Úvod}

Na konci roku 2008 zasáhl svět fenomén zvaný finanční krize. Potýkali se s ním lidé ve všech možných oborech a na různých profesních pozicích. Firmy často a většinou ve velké mîre propouštěly svoje zaměstnance. Velmi diskutovaným tématem se stala nezaměstnanost. Stížnosti lidí na nedostatek nebo absenci práce můžete slyšet kdekoliv v české republice. Je však nedostatek míst hlavním a největším problémem nezaměstnanosti?

V článku byl použit sekundární výzkum při sběru a zkoumání dat pro současný stav vědeckého poznání. Nosným bodem zde byl samotný výzkum a práce s uchazeči o práci. Výzkum byl prováděn v nadnárodní personální společnosti Manpower spol. s r.o. (dále jen personální agentura), a to po dobu pěti měsíců. Díky této dostatečně dlouhé době bylo pracováno na několika projektech. Výsledky pak vyplynuly z dlouhodobého pozorování, provádění statistického šetření a také na základě interwiev se zaměstnanci personální agentury, kteří mají na starosti obsazování pracovních míst pro svoje klienty vhodnými uchazeči. Tím, že každá pracovnice, popřípadě každý pracovník se stará o jednoho velkého klienta nebo o dva až tři menší, probíhalo interwiev bez problémů. Dále byly výpovědi pracovníků doloženy reporty, které jsou archivovány a ze kterých se dělají i statistické analýzy a různá šetření. 


\section{Chování zaměstnanců ve firmách}

Chování zaměstnanců v pracovním procesu nemusí být vždy bezproblémové. Naopak se někdy setkáváme s projevy negativního chování. Co patří mezi nejčastější projevy problematického chování zaměstnanců.

Existuje několik druhů problematického jednání zaměstnanců. Jedná se tak například o hrubé chování $\mathrm{k}$ nadřízeným a spolupracovníkům, neustálé porušování pravidel výkonu práce či pravidel spojených s pracovní pozicí, neoprávněné zveřejňování důvěrných informací vedoucích $\mathrm{k}$ poškození organizace nebo pracovníka, nedostatečně omluvené absence, opakované pozdní prríchody, nadměrné osobní telefonické rozhovory v pracovní době (Cermanová; 2005).

Někdy se můžeme setkat s diferencovanými podobami krádeží na pracovišti. Jedná se o širokou škálu způsobů okrádání zaměstnavatelů. Od drobných kancelářských pomůcek, přes nadměrnou spotřebu energie po krádeže specializovaných pracovních pomůcek či surovin. (Bailey, A. A.; 2006).

Dozvědět se, proč k takovému chování u pracovníků dochází, není jedna z nejlehčích věcí. Do hry vstupuje spousta psychologických faktorů spolu s fyziologickými potřebami a životní etapou, kterou zrovna ten který pracovník prochází. Většinou za příčinou problémů zaměstnanců na pracovišti může stát i negativní př́istup zaměstnavatelů $\mathrm{k}$ zaměstnancům. Nastolení př́kazové politiky uvnitř podniku pak vede k tomu, že zaměstnanci si potřebují tento nátlak někde vykompenzovat.

Naopak, pokud se zaměstnavatelé snaží vyjít vstříc svým zaměstnancům, snaží se pochopit jejich potřeby i zájmy, a těmto pak přizpůsobit svoje jednání a pracovní prostředí, zaměstnanci jsou k firmě loajálnější. Jsou ochotni pracovat s větším nasazením, nemají časté absence a jsou ochotni pracovat i přesčas. Samozřejmě za tuto činnost čekají náležité ocenění nebo ohodnocení.

Svým chováním tak udržují dobré jméno podniku, snižují náklady, které by souvisely s fluktuací zaměstnanců a vytváŕí větší hodnot pro zákazníky. Dále spokojení zaměstnanci chtějí setrvat ve své práci a doporučují ji jakou vhodné zaměstnání.(Škarková, D., 2001).

Na spokojenost a nespokojenost zaměstnanců má také vliv pracovní prostředí. Pokud bychom se zabývali kancelářskými prácemi, velmi důležité je osvětlení, zařízení kanceláří, barva na stěnách a výzdoba a zeleň. Nejen v kancelářích, ale zejména ve výrobním prostředí je pak důležitá otázka hluku. Hlučné a prašné prostředí znamená pro některé jedince značný problém.

Abychom se mohli více vyjádřit $\mathrm{k}$ tomu, jak zaměstnanci vnímají práci a brigády $\mathrm{v}$ době finanční krize, je nutné ještě zmínit i význam vzdělávání ve společnostech, který za poslední roky výrazně vzrostl. Nejen, že se zvyšuje poptávka ze strany zaměstnanců, tak také nabídka ze strany zaměstnavatelů. Každý uchazeč o práci ví, že i po vystudování školy se musí neustále vzdělávat a jedná se o běh na dlouhou trat'. Díky vzdělání si rozšśří svoje obzory, získá množství informací potřebných k výkonu práce a zvýší svoji hodnotu na trhu práce. Zaměstnavatelé pak vybírají takové vzdělávání a kurzy pro svoje pracovníky, které vychází z požadavků na danou pozici. Chtějí tak především u svých pracovníků rozvíjet schopnosti a dovednosti potřebné $\mathrm{k}$ výkonu povolání. Tímto zvyšují konkurenceschopnost firmy, zvýší prestiž značky a v očích uchazečů jako zaměstnavatelé vypadají tyto firmy atraktivněji. 
Ve studii "Are human resource practices linked to employee misconduct? A rational choice perspective", se věnuje pozornost špatnému chováním zaměstnanců ve firmách. Jsou zde diskutovány různé důvody, proč k nim dochází. A je zřejmé, že to není jev, který by se dal pozorovat na jednom určitém území. S tímto problémem se potýká v dnešní době celý svět( Werbel, J., Balkin, B. D.; 2010).

\section{Vývoj nezaměstnanosti}

V níže uvedené tabulce přehled průměrné roční nezaměstnanosti za posledních 18 let. Je zřejmé, že rok 2009 je hodně ovlivněn dopadem finanční krize. Od roku 1997 do roku 2000 začal prudký nárůst nezaměstnanosti, po roce 2000 se setkáváme s mírným poklesem a to až do roku 2003, kdy vidíme opět lehké zhoršení i po následující dva roky. Za rok 2010 je k dispozici údaj vztahující se k 1. 6. 2010, kdy se nezaměstnanost pohybuje na 8,5 \%.

Tab. č. 1 - Míra nezaměstnanosti v letech 1993 - 2010

\begin{tabular}{|l|c|c|c|c|c|c|c|c|c|}
\hline & $\mathbf{1 9 9 3}$ & $\mathbf{1 9 9 4}$ & $\mathbf{1 9 9 5}$ & $\mathbf{1 9 9 6}$ & $\mathbf{1 9 9 7}$ & $\mathbf{1 9 9 8}$ & $\mathbf{1 9 9 9}$ & $\mathbf{2 0 0 0}$ & $\mathbf{2 0 0 1}$ \\
\hline $\begin{array}{l}\text { Míra } \\
\text { nezaměstnanosti }\end{array}$ & 4,3 & 4,3 & 4 & 3,9 & 4,8 & 6,5 & 8,7 & 8,8 & 8,1 \\
\hline & $\mathbf{2 0 0 2}$ & $\mathbf{2 0 0 3}$ & $\mathbf{2 0 0 4}$ & $\mathbf{2 0 0 5}$ & $\mathbf{2 0 0 6}$ & $\mathbf{2 0 0 7}$ & $\mathbf{2 0 0 8}$ & $\mathbf{2 0 0 9}$ & \begin{tabular}{c}
$\mathbf{2 0 1 0}$ \\
\hline $\begin{array}{l}\text { Míra } \\
\text { nezaměstnanosti }\end{array}$
\end{tabular} \\
\hline
\end{tabular}

Zdroj: http://www.czso.cz/csu/edicniplan.nsf/aktual/ep-3

Po roce 1990 byla míra nezaměstnanosti velmi nízká ve srovnání nejen s ostatními postkomunistickými zeměmi. Velkou zásluhu na tom měl fakt, že mnoho propouštěných pracovníků vlastně jen přešlo do jiného sektoru a to do sektoru služeb, anebo do podnikání. Protože právě po roce 1989 se začalo dařit drobným podnikatelům. V roce 1999 už vidíme větší nárůst nezaměstnanosti. Ten by se dal také přičítat další vlně propouštění, tentokrát kvůli technologickému pokroku.

\section{Sociální aspekty nezaměstnanosti}

Každý stát se musí potýkat s nepopulárním jevem nezaměstnanosti. Problémy spojené s nezaměstnaností nespočívají pouze ve snížení efektivity ekonomického systému a v mrhání lidskými zdroji, v rostoucích deficitech státních rozpočtů a v měnové nestabilitě, ale jedná se také o druh sociální krize, kterou doprovází růst chudoby, snižování životní úrovně obyvatelstva a v neposlední řadě i zvyšování kriminality a jiných sociálně patologických jevů (Mareš; 1998).

V dnešní době můžeme nezaměstnanost za masovou již považovat. Příčinou je fenomén zvaný finanční krize. Na první pohled je patrné, že nezaměstnanost není v České republice rovnoměrně rozložena. Některé oblasti zasahuje více než jiné.

Pokud se budeme zabývat místo nezaměstnaností zaměstnaností a podíváme se na údaje z Eurostatu z konce roku 2009 (uvedeno 6 zemí s nejvyšší mírou zaměstnaností), zjistíme, že míra zaměstnanosti v ČR se pohybuje na vyšší úrovni, než je průměr za 27 členských zemí EU. Pouze zaměstnanost žen je nižší v řádu dvou až tří procent než je průměrná zaměstnanost $\checkmark$ EU. 
Tab. č. 2 - Míra zaměstnanosti ve vybraných zemích EU za 3. čtvrtletí r. 2009

\begin{tabular}{|l|c|c|c|c|c|c|}
\hline \multirow{2}{*}{ Země } & \multicolumn{6}{c|}{ 3. čtvrtletí 2009 } \\
\cline { 2 - 8 } & \multicolumn{3}{|c|}{$\mathbf{1 5} \mathbf{- 6 4}$ let } & \multicolumn{3}{c|}{$\mathbf{5 5} \mathbf{- 6 4}$ let } \\
\cline { 2 - 7 } & celkem & muži & ženy & celkem & muži & ženy \\
\hline EU & 74,8 & 71 & 58,7 & 46,2 & 54,9 & 37,9 \\
\hline Rakousko & 72,3 & 77,8 & 66,8 & 41,2 & 51,5 & 31,5 \\
\hline Belgie & 61,4 & 67 & 55,8 & 35,9 & 43,5 & 28,5 \\
\hline Bulharsko & 63,1 & 67,4 & 58,9 & 46,7 & 54,8 & 39,7 \\
\hline Kypr & 70 & 78 & 62,3 & 57,3 & 73,5 & 41,5 \\
\hline Česká republika & $\mathbf{7 5 , 2}$ & $\mathbf{7 3 , 7}$ & $\mathbf{5 6 , 5}$ & $\mathbf{4 6 , 4}$ & $\mathbf{5 8 , 9}$ & $\mathbf{3 4 , 8}$ \\
\hline Dánsko & 76,3 & 78,9 & 73,7 & 59 & 66,4 & 51,6 \\
\hline
\end{tabular}

Zdroj:

http://epp.eurostat.ec.europa.eu/portal/page/portal/publications/collections/news_releases

\section{Chování uchazečů o práci}

Jak působí chování kandidátů o práci na nezaměstnanost v České republice? Je možné postavit hypotézu, že zaměstnanci svou neochotou pracovat snižují konkurenceschopnost MSP v ČR a zvyšují tak negativní vliv finanční krize, která vypukla v roce 2008. Místo práce většina $\mathrm{z}$ uchazečů zůstává na úřadu práce, jsou závislí na sociálních dávkách od států a snižují tak aktivní hospodářství v naší republice. Během léta 2010 byl proveden výzkum v personální agentuře. Získané údaje byly zpracovány do tabulek a grafů a byly vyvozeny závěry uvedené v článku.

V Jihomoravském kraji se nachází několik velkých výrobních podniků. Některé z nich spolupracují s mnohými personálními agenturami, které mají za úkol pro ně hledat pracovníky a těmi osvědčenými obsazovat směny. Děje se tak po dobu, pokud tito lidé mají uzavřenou dohodu o pracovní činnosti př́ípadně dohodu o provedení práce. Pokud přechází do „kmene“, o jejich obsazování se stará už nadále personální oddělení té které společnosti nebo mistr směny. Právě tady se začínají projevovat první známky neochoty lidí pracovat a jejich nespolehlivost.

Ve výše uvedeném případě dochází zřídkakdy k tomu, aby pracovníci nedošli na svoje směny. Pokud se nemohou dostavit na směnu, děje se tak zejména ze zdravotních důvodů, které jsou nahlášeny většinou dva dny předem. To znamená, že personální agentura má dostatek času směnu obsadit zatím nevyužitým pracovníkem, anebo zaměstnat nového uchazeče. Hned na začátku pracovního poměru se většinou pozná, zda uchazeč bude spolehlivý nebo nikoliv. Pokud se pracovník nedostaví na pracoviště bez předchozí omluvy, je s ním okamžitě rozvázána pracovní smlouva. V některých případech, kdy se toto děje opakovaně nebo má zaměstnanec problémy s kázní, může být i vyloučen ze seznamu uchazečů o práci v personální agentuře. Jedná se však zhruba o $0,5 \%$ těchto uchazečů.

Další formou zaměstnávání jsou brigády. U tohoto způsobu zaměstnávání jsou daleko větší problémy.

Jako vzorový př́klad vezmeme jeden nejmenovaný projekt, který probíhal pět měsíců na území celé České republiky. Podílelo se na něm několik firem a stovky brigádníků. Plat byl sjednán hodinový - $100 \mathrm{Kč} \mathrm{za} \mathrm{hodinu.} \mathrm{Jednalo} \mathrm{se} \mathrm{o} \mathrm{pracovní} \mathrm{vztah} \mathrm{-} \mathrm{dohoda} \mathrm{o} \mathrm{pracovní}$ činnosti. 
Přihlašovali se zájemci zejména:

- z řad studentů,

- důchodců,

- maminek na MD,

- ale i lidí, kteří byli někde zaměstnáni na HPP (z 99 \% to byli lidé z vesnic a menších měst)

Zájemci o brigádu byli uloženi v databázi podle jednotlivých krajů. Brigády probíhaly podle předem stanovených rozpisů, které měli všichni uchazeči k dispozici na internetu.

Jednotlivé dny, kdy práce probíhala, začaly být obsazovány asi týden dopředu. Všichni, kteří připadali v úvahu z hlediska dojezdové vzdálenosti, a bylo pro ně ten den využití, byli osloveni telefonicky. Při telefonním hovoru s nimi byly sjednány veškeré podrobnosti, které jim pak byly ještě poslány emailem. Měli tedy veškeré informace a odsouhlasili účast na brigádě.

Jak ovšem dopadly výsledky brigád? V tabulce jsou vybrány dny, které zastupují určité měsíce, a které jsou přesně popsány množstvím potřebných pracovníků, množstvím vyměněných pracovníků den nebo půl den dopředu a také je zde zachyceno množství pracovníků, kteří se na směnu vůbec nedostavili bez omluvy nebo udání důvodu. Dny jsou vybrány z různých měsíců. 1. den zastupuje měsíc červen, 2. a 3. se konala brigáda v červenci a poslední 4. a 5. den se jedná o měsíc srpen.

Tab. č. 3 - Přehled počtu pracovníků

\begin{tabular}{|l|c|c|c|c|c|}
\hline & 1. den & 2. den & 3. den & 4. den & 5. den \\
\hline Počet požadovaných brigádníků & 202 & 180 & 232 & 12 & 23 \\
\hline Omluveno minimálně 1 den dopředu & 38 & 50 & 29 & 0 & 0 \\
\hline Nedostavilo se bez omluvy & 13 & 9 & 4 & 0 & 0 \\
\hline $\begin{array}{l}\text { Nedostavilo se bez omluvy, ale sjednali za sebe } \\
\text { náhradu }\end{array}$ & 1 & 5 & 2 & 0 & 0 \\
\hline
\end{tabular}

Zdroj: vlastní výpočty

V tabulce lze vyčíst, že měsíc srpen byl v procentech spolehlivých sčítačů nejlepší. Všichni domluveni brigádníci se zúčastnili brigády. Nutno dodat, že v tomto měsíci se pohybujeme ve velmi nízkých číslech potřebných brigádníků oproti jiným měsíců.

\section{Aktivní docházka brigádníků - pracovníků}

Otázka, která se ted' před námi otevírá, zní, jak zajistit aktivní docházku brigádníků na pracoviště? Brigádníkủm pracujícím na tomto projektu byly položeny dvě otázky. Bylo osloveno 64 lidí, z toho 13 se k otázkám nevyjádřilo vůbec, 20 odpovědělo pouze na první otázku, protože nemělo problém s docházkou, a zbytek, 31 lidí, odpovídalo na otázku druhou. 
- První otázka: Co vás nutí přijít řádně a včas na pracoviště?

Tab. č. 4 - Výsledky průzkumu 1

\begin{tabular}{|l|c|}
\hline Důvod & Množství vyjádřené v procentech \\
\hline Rodiče & $45 \%$ \\
\hline Partner (ka) & $10 \%$ \\
\hline Momentální nedostatek peněz & $70 \%$ \\
\hline Potvrzení účasti pracovníkům agentury & $48 \%$ \\
\hline
\end{tabular}

Zdroj: vlastní výpočty

- Druhá otázka: Co by vás donutilo určitě přijít na směny, na které jste byli domluveni s pracovníky agentury?

Tab. č. 5 - Výsledky průzkumu 2

\begin{tabular}{|l|c|}
\hline Důvod & Množství vyjádřené v procentech \\
\hline Zvýšení mzdy & $20 \%$ \\
\hline Vyloučení z databáze brigádníků projektu & $85 \%$ \\
\hline Sankce za absence na pracovišti & $45 \%$ \\
\hline
\end{tabular}

Zdroj: vlastní výpočty

Brigádníci často na dané otázky uváděli dvě či tři možné varianty odpovědí. Proto se v tabulce při součtu procent nedostaneme na základ $100 \%$, ale výšs.

Když se budeme věnovat první tabulce, která skýtá odpověd’ na otázku, co vede lidi k tomu, aby se dostavovali řádně do práce, zjistíme, že nejčastěji to je momentální neuspokojivá finanční situace. Za další se v tomto případě jedná o lidi, kteří mají hlubokou morálku a jsou schopni dostát domluvě s personalistou. Jelikož se zde pohybují hodně studenti, není překvapivé, že do práce jsou nuceni tito lidé právě rodiči, ve výjimečných prŕípadech pak svými životními partnery.

Tabulka druhá ukazuje odpovědi na otázku, co by lidi přinutilo si více uvědomit svoje povinnosti a chodit do práce. Jednoznačně je to vědomí o tom, že za svoje chování mohou být a jsou vyloučeni z databáze. Toto je sporná odpověd' a opět svědčí o nevnímavosti těchto pracovníků, nebot' tato možnost jim byla při podpisu smlouvy sdělena. Dále zde uvádí zvýšení mzdy. Což je velice atraktivní záležitost pro obyvatele Brna. Lidé z ostatních míst v Jihomoravském kraji jsou spokojeni s ohodnocením 100 Kč za hodinu a shledávají je atraktivním. Právě s pracovníky žijícími v Brně byli největší problémy z hlediska dodržení sjednané docházky a délky pracovní doby.

Zmiňovali také další, velice důležitou věc, která není uvedena v tabulce. Jedná se o placení sociálního a zdravotního pojištění a daně z př́ijmu, protože práce byla sjednána na dohodu o pracovní činnosti. Hlavně u studentů vysokých škol, kteří mají povědomí o výpočtu mzdy, se stávalo, že si hlídali výši mzdy. Aby nemuseli odvádět sociální a zdravotní pojištění, nesmí prekekročit 2.000 Kč. Hlásili si směny jen do doby, dokud si tuto částku nevydělali. Př́ípadně pak často rušili směny. Tento problém by mohl být řešen uzavřením Dohody o provedení 
práce, ale je to na zvážení zaměstnavatele i zaměstnanců. Zejména pak těch zaměstnanců, kteří pod agenturou dělají na více brigádách, protože jejich práce nesmí u jednoho zaměstnavatele přesáhnout 150 hodin za rok. Určitě by se tím pak ztížila agenda personální agentury, takže se to nedá považovat za nejlepší řešení.

Na závěr by se ještě nemělo zapomínat na poslední aspekt, a to nepříznivé počasí, za kterého brigáda nelze kvalifikovaně probíhat.

V následujícím přehledu je znázorněn celkový počet brigádníků, kteří se přihlásili na práci, a byla s nimi sepsána smlouva. Na black listu se ocitli ti, kteří bez omluvy nechodili pracovat nebo se sami odhlásili, neoslovovaní jsou ti, kteří již pracovali, ale neosvědčili se. Jejich práce byla chybová.

Tab. č. 6 - Souhrn a dělení pracovníků

\begin{tabular}{|c|c|c|c|}
\hline Brigádníci celkem & Důvěryhodní brigádníci & Black list & Neoslovovaní \\
\hline 441 & 352 & 28 & 61 \\
\hline
\end{tabular}

Zdroj: Interní data agentury

Graf č. 1 - Grafické procentuální vyjádření brigádníků.

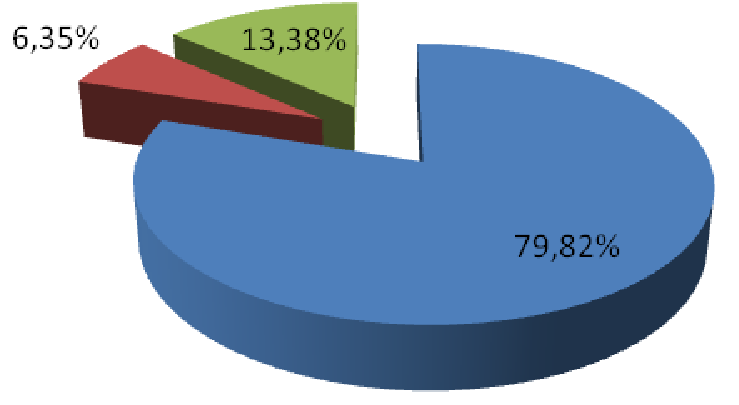

— Důvěryhodní brigádníci

Black list

neoslovovaní

Zdroj: Interní data agentury

\section{Závěr}

V současné době je ekonomická aktivita všech subjektů ovlivněna finanční krizí. Ta způsobila pád vysokého počtu podniků a tím zvýšila nezaměstnanost. Lidé, hledající si práci se stále na tuto skutečnost odkazují. Ovšem jejich chování při hledání zaměstnání je často nezodpovědné. Některým vyhovuje situace, kdy nepracují, jsou vedeni na Úřadu práce a chodí na nárazové brigády. Tímto svým chováním ještě více ztěžují pozici malých, stř̌edních i velkých podniků v České republice, které hledají pracovníky at' už na hlavní pracovní poměr nebo na brigády. Tímto jednání i přímým způsobem ztěžují uzdravení MSP v České republice po otřesu finanční krizí. V těchto firmách se často nevyskytují odborníci přes personalistiku, jejichž náplní by bylo opakované hledání nových pracovníků. Zaměstnance si tak vybírají převážně sami ředitelé nebo manažeři, případně jednatelé firem. Jsou tak obírání o čas, který by mohli věnovat obchodu a rozvoji firmy. Pokud by se tedy morální hodnoty pracovníků v České republice zvýšili, určitě by se zvýšila i konkurence schopnost malých a středních podniků, na které krize měla velký vliv a do přištího roku se počítá s dalším ohrožením těchto subjektů v podobě zvýšených cen za energii. 
Personálním agenturám, personalistům, ale také ředitelům a dalším vedoucím pracovníkům v jednotlivých podnicích tak nezbývá často nic jiného než stále hledat nové a nové zaměstnance. Východiskem z této situace by bylo, kdyby se zvýšily mzdy, stát by nezvyšoval daňové povinnosti a udělal takovou koncepci podpory v nezaměstnanosti, která by přinutila lidi více aktivně hledat práci a být ke svému zaměstnavateli loajální. Do té doby je úkolem uchazečů o práci podstupovat náročné testy a pohovory, aby se předešlo obsazování volných míst lidmi, kteří nemají dostatečnou kvalifikaci a chut' a vůli pracovat.

\section{Literatura:}

[1] ARMSTRONG, M. Řízení lidských zdrojů. Josef Koubek. Praha : Grada Publishing, 2002. 856 s. ISBN 80-247-0469-2.

[2] BAILEY, A. Retail employee theft: a theory of planned behavior perspective. International Journal of Retail \& Distribution Management . 2006, 11, 34, s. 802-816. Dostupný také z WWW:

$<$ http://www.emeraldinsight.com/search.htm?PHPSESSID=pvkl1bvprs12325d36gj1188 c0\&st $1=$ Retail+employee+theft\&ct=all\&go=Go $>$. ISSN 0959-0552.

[3] CERMANOVÁ, Tatiana . Příčiny problematického chování zaměstnanců - klíč k řešení. Noviny pro personalisty a management [online]. 22.7.2005, 6, [cit. 2010-09-03]. Dostupný z WWW: <http://www.hrportal.cz/priciny-problematickeho-chovanizamestnancu-klic-k-reseni-cid126695/>. ISSN 1214-4541.

[4] Český statistický úřad [online]. 2010 [cit. 2010-09-03]. Zaměstnanost a nezaměstnanost v ČR podle výsledků výběrového šetření pracovních sil 1. čtvrtletí 2010. Dostupné z WWW: <http://www.czso.cz/csu/edicniplan.nsf/aktual/ep-3>.

[5] European Commission : Eurostat [online]. 2010 [cit. 2010-05-04]. Register I Links I Contact I Important legal notice Employment rate in the EU27 . Dostupné z WWW: $<$ http://epp.eurostat.ec.europa.eu/portal/page/portal/publications/collections/news_relea ses>.

[6] TURECKIOVÁ, M. Řízení a rozvoj lidí ve firmách. 1. vyd. Praha : Grada Publishing, 2004. 168 s. ISBN 80-247-0405-6.

[7] ŠKARKOVÁ, Daniela. Vztah zaměstnanců k firmě : jak jej můžeme měřit a jakou má souvislost se strategií firmy. IT SYSTEM [online]. 2001, 1-2/2001, [cit. 2010-09-03]. Dostupný z WWW: <http://www.systemonline.cz/clanky/vztah-zamestnancu-kfirme.htm>. ISSN 1802-615X.

[8] WERBEL, J.,BALKIN, B. D. Are human resource practices linked to employee misconduct? A rational choice perspective. Human Resource Management Review. 2010.p. $317-326$.

\section{Klasifikace JEL: E24, J64}

\section{Ing. Petra Koudelková}

Ústav managementu,

Fakulta podnikatelská

Vysoké učení technické v Brně

Kolejní 2906/4, 61200 Brno

koudelkova@fbm.vutbr.cz 